\title{
Long term follow up of topical mustine treatment for cutaneous Langerhans cell histiocytosis
}

\author{
Peter H Hoeger, Vasanta R Nanduri, John I Harper, David A Atherton, Jon Pritchard
}

Department of Dermatology and Institute of Child Health, Great Ormond Street Hospital for Children NHS Trust, London, UK

P H Hoeger

J I Harper

D A Atherton

Department of Haematology/Oncology, Great Ormond Street Hospital for Children V R Nanduri

Department of Surgery, Great Ormond Street Hospital for Children J Pritchard

Correspondence to: Dr P H Hoeger, University of Hamburg, Department of Dermatology, Division of Paediatric Dermatology, Martinistr. 52, D-20246 Hamburg, Germany email:

hoeger@uke.uni-hamburg.de

Accepted 16 November 1999

\begin{abstract}
Background and objectives-Skin lesions in Langerhans cell histiocytosis (LCH) are often painful and difficult to treat. Topical application of nitrogen mustard $(0.02 \%$ mechlorethamine hydrochloride, mustine), an alkylating cytostatic agent, has been shown to be effective. There is, however, concern about potentially harmful long term side effects.

Study design-In a retrospective study 20 children with LCH (average extent of initial skin involvement: $16.4 \%$ body surface) were followed up for an average of 8.3 years after completion of topical mustine therapy. They had received a total of 34 courses (mean duration 14.2 weeks) of topical mustine. Disease status on follow up was assessed according to the Histiocyte Society classification.

Results-After mustine was introduced, 16 patients were able to discontinue systemic steroids and/or chemotherapy. Topical mustine was well tolerated in 18 patients, but two developed irritant dermatitis. On follow up, the disease was inactive in 10 patients. Among the children with active disease, six had mild skin disease and four had progressive disease, two of them with skin lesions unresponsive to mustine treatment. Scars confined to areas of formerly active skin disease were
\end{abstract}

evidence of premalignant or malignant skin disease in the treated areas.

Conclusion-Topical mustine is an effective and safe treatment for skin disease in most children with LCH. Residual scarring was probably a result of the disease itself rather than to mustine. Although no evidence of skin cancer was found in this study, continued long term follow up is advisable.

(Arch Dis Child 2000;82:483-487)

Keywords: cutaneous LCH; topical chemotherapy; long term follow up

Langerhans cell histiocytosis ( $\mathrm{LCH})$ is a clonal proliferative disorder of cells derived from the Langerhans cells population that involves skin, bone, and other tissues. ${ }^{12}$ Skin involvement is characterised by chronic or recurrent eruptions of erythematous, scaly papules especially in the intertriginous (retroauricular, inguinal, perianal, and axillary) regions. Skin lesions are itchy and tend to ulcerate. Deep and painful fissures that become secondarily infected are common and often unresponsive to topical steroid treatment. ${ }^{1-4}$

Nitrogen mustard (mechlorethamine hydrochloride, mustine) is an alkylating antitumour agent discovered in the 1940s and used in the treatment of Hodgkin's disease. ${ }^{5}$ It has also been used successfully as a topical agent in

Table 1 Disease extent, previous treatment, and details of mustine treatment in 20 children with LCH

\begin{tabular}{|c|c|c|c|c|c|c|c|}
\hline $\begin{array}{l}\text { Patient } \\
\text { no }\end{array}$ & Sex & $\begin{array}{l}\text { Extent of skin } \\
\text { disease (\% of } \\
\text { body surface) }\end{array}$ & $\begin{array}{l}\text { Involvement of } \\
\text { other organs }\end{array}$ & $\begin{array}{l}\text { Treatment prior } \\
\text { to mustine }\end{array}$ & $\begin{array}{l}\text { Number and } \\
\text { duration of mustine } \\
\text { courses (wk) }\end{array}$ & $\begin{array}{l}\text { Time to response } \\
\text { of skin rash } \\
(w k)\end{array}$ & $\begin{array}{l}\text { Side effects } \\
\text { of mustine }\end{array}$ \\
\hline 1 & $M$ & 3 & $\mathrm{LN}$ & $\begin{array}{l}\text { VB, VP16, } \\
\text { HDMP }\end{array}$ & $2(12 / 4)$ & 4 & 0 \\
\hline 2 & M & 32 & B, DI, G & VP16 & $1(12)$ & 4 & 0 \\
\hline 3 & $\mathrm{~F}$ & 23 & - & - & $3(3 / 3 / 3)$ & 2 & 0 \\
\hline 4 & $M$ & 9 & B, DI, G & HDMP, VP16 & $3(2 / 2 / 1)$ & 2 & 0 \\
\hline 5 & $\mathrm{~F}$ & 7 & $\mathrm{~B}, \mathrm{G}$ & - & $2(36 / 8)$ & 4 & 0 \\
\hline 6 & $M$ & 7 & $\mathrm{~B}, \mathrm{LN}, \mathrm{G}$ & $\begin{array}{l}\text { P, AZ, VP16, } \\
\text { RxT, VB }\end{array}$ & $1(6)$ & $>6$ & 0 \\
\hline 7 & $\mathrm{~F}$ & 21 & B, DI & $P, V B$ & $2(28 / 4)$ & 4 & 0 \\
\hline 8 & $M$ & 15 & $\mathrm{~B}, \mathrm{DI}, \mathrm{L}, \mathrm{G}$ & $\mathrm{P}$ & $1(4)$ & $2-3$ & 0 \\
\hline 9 & $M$ & 26 & - & - & $1(12)$ & 4 & 0 \\
\hline 10 & M & 24 & B & $\mathrm{P}$ & $2(16 / 4)$ & 6 & 0 \\
\hline 11 & M & 15 & $\mathrm{~B}, \mathrm{BM}, \mathrm{GI}, \mathrm{G}$ & $\begin{array}{l}\text { HDMP, 6MP, } \\
\text { VB, VP16, CsA }\end{array}$ & $1(4)$ & 4 & 0 \\
\hline 12 & M & 11 & B, DI, L, G, CNS & VB & $1(20)$ & $2-3$ & 0 \\
\hline 13 & M & 11 & B, DI, L, G & P, VP16 & $3(6 / 4 / 1)$ & $1-2$ & $\begin{array}{l}\text { Irritative } \\
\text { dermatitis }\end{array}$ \\
\hline 14 & M & 10 & DI, L, CNS & $\mathrm{P}$ & $1(12)$ & 1 & 0 \\
\hline 15 & $\mathrm{M}$ & 15 & DI, LN, G & - & $2(4 / 4)$ & 4 & 0 \\
\hline 16 & $\mathrm{~F}$ & 15 & B & - & $1(12)$ & $2-3$ & 0 \\
\hline 17 & $M$ & 9 & B, DI, BM, L & VC, $\mathrm{P}$ & $2(4 / 4)$ & 1 & 0 \\
\hline 18 & M & 50 & $\begin{array}{l}\text { B, BM, GI, G, C, } \\
\text { LN }\end{array}$ & $\begin{array}{l}\text { VP16, HDMP, } \\
\text { VB, MTX }\end{array}$ & $3(8 / 4 / 4)$ & $2-4$ & $\begin{array}{l}\text { Irritative } \\
\text { dermatitis }\end{array}$ \\
\hline 19 & $M$ & 8 & B, DI, GI, L, G & HDMP & $1(20)$ & 3 & 0 \\
\hline 20 & $\mathrm{~F}$ & 16 & B & $\mathrm{P}$ & $1(10)$ & 1 & 0 \\
\hline
\end{tabular}

LN, lymph node; B, bone; DI, diabetes insipidus; G, gingiva; L, lung; BM, bone marrow; GI, gastrointestinal tract; C, conjunctival; VB, vinblastine; HDMP, high dose methylprednisolone; VP16, etoposide; P, prednisolone; AZ, azathioprine; RxT, radiotherapy; 6MP, 6-mercaptopurine; CsA, cyclosporin A; VC, vincristine; MTX, methotrexate. 

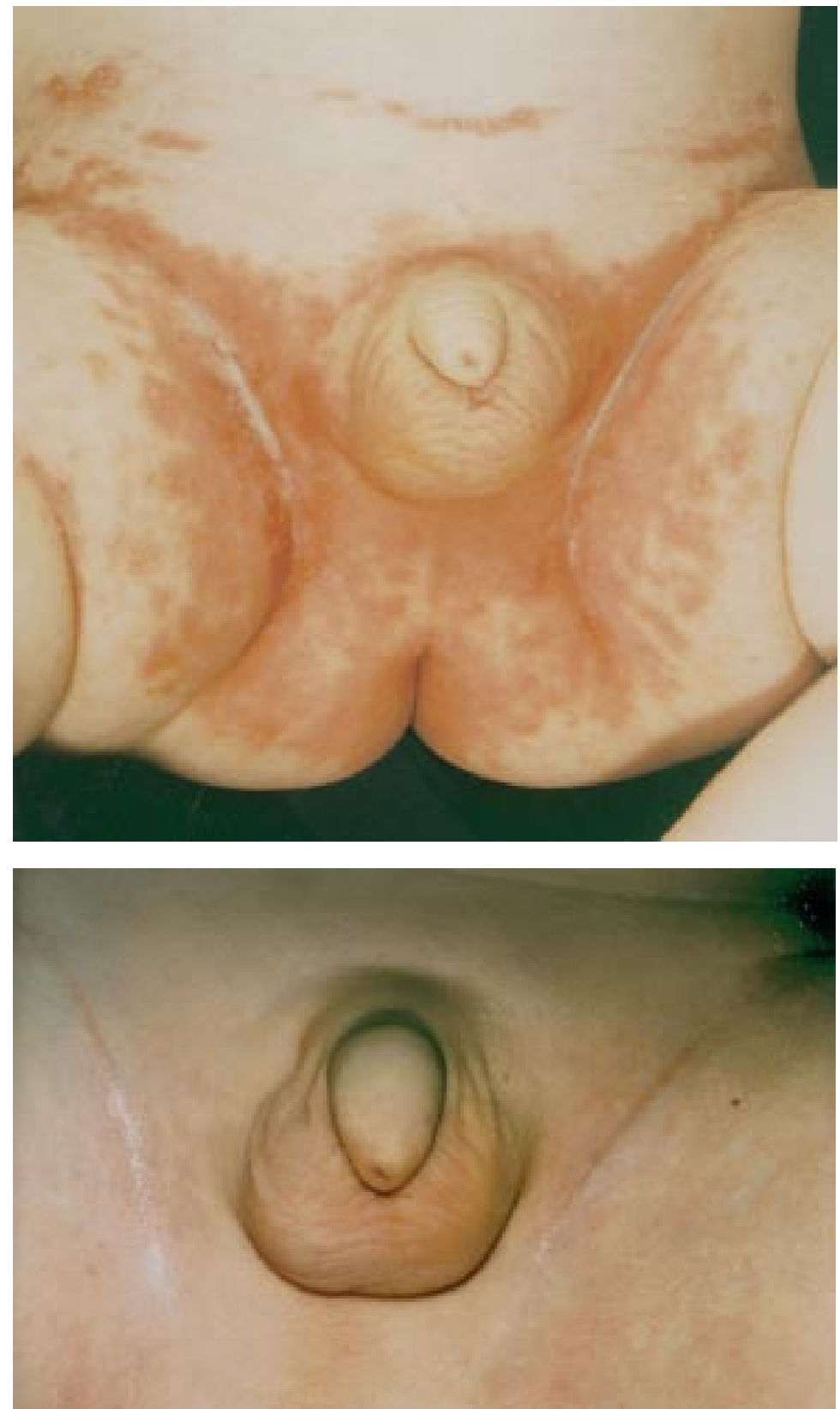

Figure 1 Patient 19 before (top) and 1 year after (bottom) topical mustine therapy.

mycosis fungoides ${ }^{6}$ and psoriasis. ${ }^{7}$ In $\mathrm{LCH}$, mustine is effective against skin lesions. ${ }^{2-10}$ There is, however, concern about potential toxic longterm side effects of mustine, especially as there is evidence that the drug can be oncogenic. Topical mustine can induce tumours in mice, possibly by enhancing ultraviolet $\mathrm{B}$ photocarcinogenesis, ${ }^{11}$ and increased rates of skin cancer (squamous cell carcinoma, basal cell carcinoma) have been observed in patients with psoriasis and mycosis fungoides, respectively, after topical application of mustine. ${ }^{12-18}$ It is also of concern that high rates of contact sensitivity were reported in adults treated with mustine. ${ }^{19-21}$ In other reports, however, topical mustine was well tolerated and safe, both in the short term ${ }^{9}$ and after long term follow up. ${ }^{6223}$

Given this information, and as we have a relatively large cohort of children with $\mathrm{LCH}$, we systematically followed up on our patients treated with topical mustine between 1983 and 1998. We were particularly interested in collecting details of the duration and dose of mustine and the time until clearance of skin lesions as well as the prevalence of local or general side effects. Overall outcome was also assessed.

\section{Patients and methods}

PATIENTS

Between 1983 and 1997, 67 of 155 new LCH patients seen in our haematology/oncology department had skin involvement. In 20 of them the degree and type of skin involvement were considered to justify topical mustine treatment ${ }^{9}$ because they were sufficiently severe (pruritic, ulcerating, or fistulating) and unresponsive to topical and oral steroids. Medical records of these 20 patients, who were followed up to 1997-99, were reviewed in detail. LCH was diagnosed according to standard histological criteria ${ }^{24}{ }^{25}$ at a mean age of 18.2 months (range 2-108, median 12.5). Using criteria proposed by the coordinators of the LCH-1 Treatment Protocol, ${ }^{24}$ the average extent of skin involvement was $16.4 \%$ of the body surface (range 3-50\%, median 15\%). Lesions were most common in the scalp and inguinal region (in $90 \%$ and $85 \%$ of patients, respectively). Fifteen patients also had bone involvement, diabetes insipidus (DI) was diagnosed in 10 , and various other organs (lymph nodes, lung, bone marrow, CNS, gastrointestinal tract, gingiva, and conjunctiva) were involved in a total of 14 children. Fifteen patients had also been treated with prednisolone or a variety of cytostatic drugs (table 1 ).

DETAILS OF MUSTINE TREATMENT

Nitrogen mustard powder (Boots Co., Nottingham, UK) was diluted with water to a final concentration of $200 \mathrm{mg} / \mathrm{l}$ and selectively applied to the involved skin with appropriately sized watercolour paintbrushes, as described previously. ${ }^{9}$ The initial average dose was 2-3 mg nitrogen mustard (mustine) per day. After 10 minutes, the mustine was rinsed off. The solution was applied once daily until the skin lesions started to regress. The frequency of application was then reduced to every other day, then every third day, then once weekly until complete clearance. Treatment was begun in hospital and, after appropriate training, continued by the child's parents at home. The total amount of mustine used was calculated from the number of units dispensed by our hospital pharmacy. The total dose per square metre of body surface was calculated from the amount of drug versus body weight and length, respectively, at the start of mustine treatment $\left(\mathrm{m}^{2}\right.$ body surface $=\sqrt{ }($ body weight $\times$ body length $) \div$ 3600).

FOLLOW UP INVESTIGATIONS

Clinical follow up examinations were performed by either of two physicians $(\mathrm{PHH}$, VRN) at an average of 8.3 years (range 4-174 months, median 114 months) after completion of topical mustine treatment. The outcome was 
classified into "active" and "non-active" disease according to the disease state definition of the Histiocyte Society. ${ }^{24} \mathrm{LCH}$ is regarded as non-active when all signs and/or symptoms have resolved. Active disease is subclassified into "regressing disease" (regression of signs and/or symptoms without appearance of new lesions), "stable disease" (persistence of signs and/or symptoms of disease without appearance of new lesions), and "progressive disease" (progression of signs and/or symptoms of disease initially detected and/or reappearance of old and/or appearance of new lesions). Some patients with non-active disease had residual handicaps from previously active $\mathrm{LCH}$, for example, diabetes insipidus, growth hormone deficiency, or deafness.

\section{Results}

DETAILS OF MUSTINE TREATMENT

The 20 children received a total of 34 courses of topical mustine. Average time to clearance (at least $90 \%$ reduction in size and severity of skin lesions) was 21 days (range $7-42$; table 1 ). After at least $90 \%$ clearance was obtained, treatment for individual recalcitrant lesions was often continued once weekly for periods of up to 36 weeks duration (mean 14.2 weeks). Patients received between one and three courses (average 1.7 courses; table 1). Typically, the initial courses were the longest (mean duration 11.6 weeks), while the mean duration of second treatment courses (in 10 patients) was 4.1 weeks. A third course (mean duration 2.3 weeks) was required in only four patients. Details of the doses and schedule of topical mustine were available for 10 patients (18 courses of mustine). On average, a total of

Table 2 Follow up after mustine treatment in 20 children with LCH

\begin{tabular}{|c|c|c|c|c|c|}
\hline $\begin{array}{l}\text { Patient } \\
\text { no. }\end{array}$ & $\begin{array}{l}\text { Follow up after } \\
\text { start of mustine } \\
\text { (mth) }\end{array}$ & $\begin{array}{l}\text { Current } \\
\text { medication }\end{array}$ & $\begin{array}{l}\text { Disease state } \\
\text { (involved } \\
\text { organ if not } \\
\text { skin) }\end{array}$ & $\begin{array}{l}\text { Residual } \\
\text { defects }\end{array}$ & Skin findings \\
\hline 1 & 18 & M & $\mathrm{SD}$ & - & $\begin{array}{l}\text { Draining skin } \\
\text { sinuses, scars }\end{array}$ \\
\hline 2 & 99 & DDAVP & NAD & DI & Scars \\
\hline 3 & 57 & 0 & NAD & - & $\begin{array}{l}\text { Postinflammatory } \\
\text { hyperpigmentation }\end{array}$ \\
\hline 4 & 53 & DDAVP & NAD & DI & - \\
\hline 5 & 28 & 0 & NAD & - & Scars, mild scaling \\
\hline 6 & 176 & $\mathrm{P}^{\star}$ & PD & - & $\begin{array}{l}\text { New lesions } \\
\text { (buttocks, ears), } \\
\text { scars }\end{array}$ \\
\hline 7 & 33 & DDAVP, GH & $\mathrm{RD}$ & DI, GHD & Scalp rash \\
\hline 8 & 159 & DDAVP & $\mathrm{RD}$ & DI & Mild scalp rash \\
\hline 9 & 176 & 0 & NAD & - & - \\
\hline 10 & 34 & $\mathrm{VB}, \mathrm{P} \dagger$ & PD (bone) & - & - \\
\hline 11 & 44 & $\mathrm{P} \dagger, \mathrm{GH}$ & PD (GI) & $\begin{array}{l}\text { GHD, } \\
\text { deafness }\end{array}$ & - \\
\hline 12 & 72 & DDAVP, GH & $\mathrm{RD}$ & DI, GHD & Mild scalp rash \\
\hline 13 & 191 & DDAVP, GH & NAD & DI, GHD & - \\
\hline 14 & 171 & DDAVP, GH & NAD & DI, GHD & - \\
\hline 15 & 141 & 0 & NAD & - & - \\
\hline 16 & 169 & DDAVP & NAD & $\begin{array}{l}\text { DI, GHD, } \\
\text { hydrocephalus }\end{array}$ & Scars \\
\hline 17 & 149 & 0 & NAD & $\begin{array}{l}\text { DI, GHD, } \\
\text { deafness }\end{array}$ & - \\
\hline 18 & 48 & Cyt & $\begin{array}{l}\mathrm{PD}(\mathrm{BM}, \\
\mathrm{LN})\end{array}$ & Died & $\begin{array}{l}\text { Persistent lesions } \\
\text { (scalp, ears, } \\
\text { gingiva), scars }\end{array}$ \\
\hline 19 & 156 & 0 & $\mathrm{RD}$ & Deafness & $\begin{array}{l}\text { Mild scalp rash, } \\
\text { faint scars }\end{array}$ \\
\hline 20 & 17 & 0 & $\mathrm{RD}$ & - & Mild scalp rash \\
\hline
\end{tabular}

$\mathrm{M}$, mustine; $\mathrm{P}^{\star}$, low dose prednisolone on alternate days; $\mathrm{P} \dagger, 10 \mathrm{mg}$ prednisolone daily; DDAVP, desamino-desarginino-vasopressin; $\mathrm{GH}$, growth hormone. NAD, non-active disease; $\mathrm{RD}$, regressing disease; $\mathrm{SD}$, stable disease; $\mathrm{PD}$, progressive disease. $\mathrm{BM}$, bone marrow; $\mathrm{LN}$, lymph node; $\mathrm{GI}$, gastrointestinal involvement; DI, diabetes insipidus; GHD, growth hormone deficiency.
Indications for the use of mustine for cutaneous LCH

Mustine hydrochloride $0.02 \%$ aqueous solution, applied topically (with cotton wool swabs, cotton wool buds, or paintbrushes) is indicated:

(1) When there is symptomatic skin involvement by LCH but clinically insignificant involvement of other organs, so that systemic treatment with methylprednisolone or chemotherapy is not otherwise indicated

(2) When skin involvement is symptomatic and has not responded, or responded poorly, to systemic treatment or conventional topical treatment, for example, with topical steroids

Note that:

- Mustine is effective for LCH induced fissures, scalp involvement, and involvement of the external auditory canal

- Application of mustine to mucosal surfaces may cause discomfort and should be avoided

$375.9 \mathrm{mg} / \mathrm{m}^{2}$ (range 104.3-1148.1) was applied. The dose correlated with the extent of skin involvement. After initiation of mustine treatment, all except four patients (patients 6, 10,11 , and 18) were able to discontinue systemic steroid and/or cytostatic treatment. Figure 1 shows patient 19 before and one year after topical mustine treatment.

Topical mustine was well tolerated in 18 patients; two children developed irritant dermatitis caused by the treatment and characterised by non-pruritic erythema and oedema. The cutaneous irritation regressed on discontinuation of mustine, and did not recur when it was restarted. In two children with severe multisystem LCH, chronic skin disease was unresponsive to mustine (patients 6 and 18), and one of them subsequently died (table 2 ).

FOLLOW UP INVESTIGATIONS

Scars confined to areas of formerly active skin disease were found in six patients $(30 \%)$. A similar percentage can be observed in children with cutaneous LCH not treated with mustine (unpublished data). No premalignant or malignant skin lesions were detected. Outcome evaluation revealed non-active and active disease, respectively, in $50 \%$ of the patients. Among the children with active disease, six had skin involvement. This was characterised by a mild scalp rash, resembling seborrhoeic dermatitis, that tended to improve gradually; it was classified as regressing (not requiring treatment) in five, and stable (requiring intermittent treatment) in one. Four children had progressive disease, two of them with skin lesions unresponsive to mustine treatment. Residual defects in other organ systems were noted in 12 patients (table 2).

\section{Discussion}

Topical mustine has been used in children with LCH skin involvement since $1979,{ }^{8}$ but as yet, 
no study has systematically addressed the intermediate or long term outcome. Our follow up study indicates that topical mustine is a safe and effective treatment for severe skin lesions in most children with LCH. Skin disease healed either completely or was greatly improved in $18 / 20$ patients within 21 days of mustine treatment, but - in accordance with previous reports ${ }^{9}{ }^{26}-50 \%$ of patients required two or three courses of treatment. Clearance of LCH skin lesions is more rapid and more lasting than in patients with mycosis fungoides. ${ }^{26} 27$ In $80 \%$ of our patients, no other systemic or topical drug was required to control skin lesions.

In single system LCH (usually bone, sometimes skin involvement alone), with a high rate of spontaneous regression, the basic question is whether or not treatment is needed. ${ }^{28}$ This dilemma is particularly difficult in "pure cutaneous" LCH. ${ }^{34}$ However, cutaneous LCH lesions frequently do not respond to topical agents such as steroid ointment. In case of multisystem involvement, control is usually gained with corticosteroids or chemotherapy (high dose methylprednisolone, vinblastine, or etoposide ${ }^{1224}$ ), but etoposide can cause leukaemia ${ }^{29}$ and is usually avoided if the overall prognosis is favourable. Radiation of indolent skin lesions has been abandoned, particularly in children. PUVA-chemotherapy carries an increased risk of skin cancer including malignant melanoma. ${ }^{30}$

Despite its proven efficacy, topical mustine is still not widely used for treatment of severe skin disease in LCH, largely because of lingering concern about tumourigenicity and the recognised local irritant effect of the drug in adults. ${ }^{12-21}$ Possible induction of skin cancer has been a subject of major concern since the introduction of mustine treatment for mycosis fungoides (in 1956), psoriasis (in 1959), and LCH (in 1975). ${ }^{8}{ }^{26} 27$ After a latency period of two to seven years following topical mustard, increased rates (two- to ninefold) of epithelial cancers (basal cell carcinoma, squamous cell carcinoma, actinic keratoses, or keratoakanthoma) were reported in patients both with mycosis fungoides ${ }^{12} 13151718$ and psoriasis. ${ }^{14} 16$ Because of a previous report suggesting that ultraviolet B photocarcinogenesis was increased by mustine, ${ }^{11}$ sun protection seems to be advisable during and after treatment, but skin tumours were also reported in areas not exposed to the sun, and both in areas with and without previous mustine treatment. However, as pointed out previously, ${ }^{9}$ there are several confounding factors that make it difficult to attribute premalignant and malignant skin diseases in those reports to mustine alone.

Firstly, most of these patients had also received other potentially carcinogenic treatments (ultraviolet therapy, electron beam therapy, cytostatic drugs, or arsenic). Secondly, large areas of their bodies (up to 95\% compared to $16 \%$ in our LCH patients) were exposed to topical mustine, often for much longer periods of time (on average, 81 months, and up to 12 years compared to 14 weeks-of mostly once weekly applications - in our pa- tients), and at cumulative doses that were approximately $10-100$-fold higher ${ }^{23}$ than in our patients. Finally, with a mean age of more than 50 years, the patients with psoriasis or mycosis fungoides had a much higher chance of spontaneously developing epithelial cancers. Interestingly, Studstrup et al were unable to detect DNA damage (sister chromatid exchanges) in lymphocytes after in vitro exposure to topical mustine. ${ }^{22}$ After a mean follow up period of 8.3 years, we found no evidence of serious side effects of topical mustine treatment. Specifically, no malignant or premalignant skin lesions were noted in either treated or untreated areas. The follow up period in our study was sufficiently long to cover the previously described latency period between exposure to mustine and development of skin cancers. ${ }^{12-18}$ For the moment, our results are reassuring, but they do not, of course, rule out the development of skin cancer in later years, and clinical follow up will be continued.

The rate of local reactions to mustine was low in our patients. Irritant dermatitis was observed in only two children (10\%) and discontinuation of mustine was not required. The frequency of irritant or allergic contact dermatitis caused by mustine has been reported to be as high as $30-70 \%$ in adults, ${ }^{26}{ }^{27} 31$ while others observed it in only $15 \%$ of their patients. ${ }^{21}$ It is often difficult to differentiate between irritant/toxic and allergic reactions to mustine. ${ }^{21}$ As with its carcinogenic effects, the occurrence of irritative contact dermatitis associated with mustine is probably related to the duration and extent of its application, ${ }^{27}$ thereby explaining the discrepant reported rates of local reactions. Several effective methods for desensitisation have been described. ${ }^{26} 27$ Other cutaneous side effects include transient hyperpigmentation $^{627}$ and hypopigmentation. We found hyperpigmentation in one patient. Scars (confined to areas of former severe skin involvement) were noted in in six of 20 patients $(30 \%)$, but such changes can be observed in $\mathrm{LCH}$ patients with severe skin disease irrespective of therapy, ${ }^{3432}$ and are therefore considered a consequence of the disease, not the treatment.

In summary, topical mustine is a reasonable treatment option when skin disease is severe and systemic treatment is either unwarranted or ineffective. Preventive safety measures for patients (focal application, followed by thorough cleansing of the skin, subsequent sun protection) and for parents/personnel (gloves, face masks, gowns, hospital rooms specifically assigned for the administration of mustine ${ }^{33}$ ) must be strictly observed. Provided these precautions are taken, we and others ${ }^{2} 6910222327$ regard the actual risks of topical mustine treatment as acceptable. The principal benefit is a $90 \%$ chance of an excellent short and medium term response, with few side effects, in a condition that is at best uncomfortable and at worst life threatening.

We are grateful to Lucy Olliver, Clinical Nurse Specialist and We are grateful to Lucy Oliver, Clinical Nurse Specialist and
Ms Chin Gan, Clinical Pharmacist, both at Great Ormond Street Hospital for Children NHS Trust, London, for their supStreet Hospital for Children
port and helpful comments. 
1 Egeler RM, D'Angio GJ. Langerhans cell histiocytosis. $\mathcal{F}$ Pediatr 1995;127:1-11.

2 Munn S, Chu AC. Langerhans cell histiocytosis of the skin. Hematol Oncol Clin North Am 1998;12:269-286.

3 Esterly NB, Maurer HS, Gonzalez-Crussi. Histiocytosis X: a seven-year experience at a children's hospital. F Am Acad Dermatol 1985;13:481-96.

4 Hoeger PH, Janka-Schaub G, Mensing H. Late manifestation of diabetes insipidus in "pure" cutaneous Langerhans cell histiocytosis. Eur F Pediatr 1997;156:524-7.

5 Hancock BW, Vaughan-Hudson G, Vaughan-Hudson B, et al. British National Lymphoma Investigation randomised study of MOPP (mustine, Oncovin, procarbazine, prednisolone) against LOPP (Leukeran substituted for mustine) in advanced Hodgkin's disease-long term results. $\mathrm{Br}$ f Cancer 1991;63:579-82.

6 Zachariae H, Thestrup-Pedersen K, Soegard H. Topical nitrogen mustard in early mycosis fungoides. Acta Derm nitrogen mustard in early mycos (Stockh) 1985; 65:53-8.

7 Mandy S, Taylor JR, Halprin K. Topical applied mechlorethamine in the treatment of psoriasis. Arch Dermatol rethamine in the

8 Zachariae $\mathrm{H}$. Histiocytosis $\mathrm{X}$ in two infants treated with topical nitrogen mustard. Br f Dermatol 1979;100:433-8.

9 Sheehan MP, Atherton DJ, Broadbent V, Pritchard J. Topical nitrogen mustard: an effective treatment for cutaneous

Langerhans cell histiocytosis. F Pediatr 1991;119:317-21.

10 Irving RM, Broadbent V, Jones NS. Langerhans cell histiocytosis in childhood: management of head and neck mani-
festations. Laryngoscope 1994;104:64-70.

11 Epstein JH. Nitrogen mustard (mechlorethamine) and UVB photocarcinogenesis. A dose response effect. $\mathcal{F}$ Invest Dermatol 1984;83:320-2.

12 du Vivier A, Vonderheid EC, van Scott EJ, Urbach F. Mycosis fungoides, nitrogen mustard and skin cancer. $\mathrm{Br} \mathcal{F} \mathrm{Der}-$ matol 1978;99:61-3.

13 Kravitz PH, McDonald CJ. Topical nitrogen mustard induced carcinogenesis. Acta Dermatovener (Stockholm) induced carcin

14 Halprin KM, Comerford M, Taylor JR. Cancer in patients with psoriasis. I Am Acad Dermatol 1982;7:633-8 with psoriasis. If Am Acad Dermatol 1982;7:633-8

15 Lee LA, Fritz KA, Golitz L, Fritz TJ, Weston WL. Second cutaneous malignancies in patients with mycosis fungoides treated with topical nitrogen mustard. F Am Acad Dermato 1982;7:590-8.

16 Ganor S. Skin cancer in psoriatics treated with nitrogen mustard [letter]. F Am Acad Dermatol 1983;9:164

17 Abel EA, Sendagorta E, Hoppe RT. Cutaneous malignancies and metastatic squamous cell carcinoma following topical therapies for mycosis fungoides. F Am Acad Dermatol $1986 ; 14: 1029-38$
18 Vonderheid EC, Tan ET, Kantor AF, Shrager L, Micaily B, Van Scott EJ. Long-term efficiency, curative potential and in cutaneous T cell lymphoma. 7 Am Acad Dermatol 1989; in cutaneous

19 Daughters D, Zacheim H, Maibach H. Urticaria and anaphylactoid reactions after topical application of mechlorethamine. Arch Dermatol 1973;107:429-30.

20 Grunnet E. Contact urticaria and anaphylactoid reaction induced by topical application of nitrogen mustard. $\mathrm{Br} \mathcal{F}$ Dermatol 1976;94:101-3.

21 Goday JJ, Aguirre A, Ratón JA, Diaz-Pèrez JL. Local bullous reaction to topical mechlorethamine (mustine). Contact Dermatitis 1990;22:306-7.

22 Studstrup L, Beck HI, Bjerring P, Wulf HC, Lundgren K. No detectable increase in sister chromatid exchanges in lymphocytes from mycosis fungoides patients after topical treatment with nitrogen mustard. Br f Dermatol 1988;119: treatment

23 Nielsen M, Rasmussen K, Knudsen N, Thestrup-Pedersen $\mathrm{K}$. Long-term topical nitrogen mustard treatment does not induce pulmonary fibrosis in MF patients. Acta Derm Venereol (Stockh) 1994:74:70-1.

24 Writing Group of the Histiocyte Society. Histiocytosis syndromes in children. Lancet 1987;i:208-9.

25 Broadbent V, Gadner H, Komp DM, Ladisch S. Histiocytosis syndromes in children: approach to the clinical and aboratory evaluation of children with Langerhans cell histiocytosis. Med Pediatr Oncol 1989;17:492-5.

26 Avril MF. La caryolysine locale. Ann Dermatol Venereol 1987;114:133-41.

27 Vonderheid EC. Topical mechlorethamine chemotherapy. Considerations on its use in mycosis fungoides. Int $\mathcal{F}$ Dermatol 1984;23:180-6.

28 McLelland J, Broadbent V, Yeomans E, Malone M, Pritchard J. Langerhans cell histiocytosis: the case for conservative treatment. Arch Dis Child 1990;65:301-3.

29 Whitlock JA, Greer JP, Lukens JN. Epipodophyllotoxin related leukemia. Cancer 1991;68:600-4.

30 Stern RS, Nichols KT, Väkevä LH. Malignant melanoma in patients treated for psoriasis with methoxysalen (psoralen)
and ultraviolet A radiation (PUVA). N Engl $7 \mathrm{Med}$ 1997;336:1041-5.

31 Taylor JR, Halprin KM. Topical use of mechlorethamine in the treatment of psoriasis. Arch Dermatol 1972;106:362-4.

32 Lee CW, Park MH, Lee H. Recurrent cutaneous Langerhans cell histiocytosis in infancy. Br f Dermatol 1988;119: 259-65.

33 Van Vloten WA, Gooijmanns ACM, Poel J, Meulenbelt J. Concentrations of nitrogen mustard in the air during topimatol 1993;128:404-6. 